\title{
Do Children Who Bully Their Peers Also Play Violent Video Games? A Canadian National Study
}

\author{
Crystal J. Dittrick, Tanya Beran, Faye Mishna, Ross Hetherington \\ \& Shaheen Shariff
}

Version Post-Print/ Accepted Manuscript

Citation Dittrick, C. J., Beran, T., Mishna, F, Hetherington, R. \& Shariff, S. (published version) (2013.: Do Children Who Bully Their Peers Also Play Violent Video Games? A Canadian National Study. Journal of School Violence 12(4):297-318. DOI:10.1080/15388220.2013.803244

Publisher's Statement This is an Accepted Manuscript of an article published by Taylor \& Francis in the Journal of School Violence in 2013, available at http://www.tandfonline.com/doi/abs/10.1080/15388220.2013.803244

How to cite TSpace items

Always cite the published version, so the author(s) will receive recognition through services that track citation counts, e.g. Scopus. If you need to cite the page number of the TSpace version (original manuscript or accepted manuscript) because you cannot access the published version, then cite the TSpace version in addition to the published version using the permanent URI (handle) found on the record page. 
This article was downloaded by: [University of Toronto Libraries]

On: 24 May 2013, At: 15:52

Publisher: Routledge

Informa Ltd Registered in England and Wales Registered Number: 1072954 Registered office: Mortimer House, 37-41 Mortimer Street, London W1T 3J H, UK

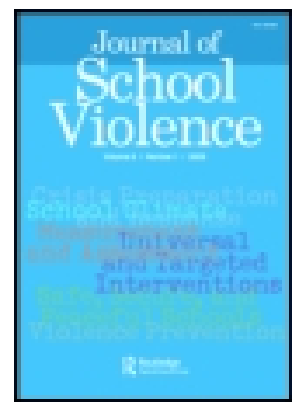

\title{
J ournal of School Violence
}

Publication details, including instructions for authors and subscription information: http:// www. tandfonline.com/loi/ wjsv20

\section{Do Children Who Bully Their Peers Also Play Violent Video Games? A Canadian National Study}

\author{
Crystal J. Dittrick $^{a}$, Tanya Beran ${ }^{b}$, Faye Mishna ${ }^{c}$, Ross Hetherington ${ }^{d} \&$ Shaheen \\ Shariff ${ }^{\mathrm{e}}$ \\ ${ }^{a}$ Educational Studies in Counselling Psychology, University of Calgary, Calgary , \\ Alberta, Canada \\ ${ }^{\mathrm{b}}$ Department of Community Health Sciences, University of Calgary, Calgary, Alberta , \\ Canada \\ ${ }^{\mathrm{C}}$ Factor Inwentash Faculty of Social Work, University of Toronto, Toronto, Ontario, \\ Canada \\ ${ }^{\mathrm{d}}$ Hospital for Sick Children, University of Toronto, Toronto, Ontario, Canada \\ ${ }^{\mathrm{e}}$ Department of Integrated Studies in Education, McGill University, Montreal, Quebec, \\ Canada \\ Accepted author version posted online: 24 May 2013.
}

To cite this article: Crystal J . Dittrick, Tanya Beran, Faye Mishna, Ross Hetherington \& Shaheen Shariff (2013): Do Children Who Bully Their Peers Also Play Violent Video Games? A Canadian National Study, J ournal of School Violence, DOI: $10.1080 / 15388220.2013 .803244$

To link to this article: http:// dx. doi.org/ 10.1080/ 15388220.2013.803244

Disclaimer: This is a version of an unedited manuscript that has been accepted for publication. As a service to authors and researchers we are providing this version of the accepted manuscript (AM). Copyediting, typesetting, and review of the resulting proof will be undertaken on this manuscript before final publication of the Version of Record (VoR). During production and pre-press, errors may be discovered which could affect the content, and all legal disclaimers that apply to the journal relate to this version also.

\section{PLEASE SCROLL DOWN FOR ARTICLE}

Full terms and conditions of use: http://www.tandfonline.com/page/terms-and-conditions

This article may be used for research, teaching, and private study purposes. Any substantial or systematic reproduction, redistribution, reselling, loan, sub-licensing, systematic supply, or distribution in any form to anyone is expressly forbidden.

The publisher does not give any warranty express or implied or make any representation that the contents will be complete or accurate or up to date. The accuracy of any instructions, formulae, and drug doses should be independently verified with primary sources. The publisher shall not be liable for any loss, actions, claims, proceedings, demand, or costs or damages whatsoever or howsoever caused arising directly or indirectly in connection with or arising out of the use of this material. 
Bullying and Video Games

\section{Do Children Who Bully Their Peers Also Play Violent Video Games? A Canadian National Study}

CRYSTAL J. DITTRICK

Educational Studies in Counselling Psychology, University of Calgary, Calgary, Alberta, Canada TANYA BERAN

Department of Community Health Sciences, University of Calgary, Calgary, Alberta, Canada FAYE MISHNA

Factor Inwentash Faculty of Social Work, University of Toronto, Toronto, Ontario, Canada ROSS HETHERINGTON

Hospital for Sick Children, University of Toronto, Toronto, Ontario, Canada

SHAHEEN SHARIFF

Department of Integrated Studies in Education, McGill University, Montreal, Quebec, Canada Received September 24, 2012; accepted April 22, 2013.

Address correspondence to Tanya Beran, Department of Community Health Sciences, Faculty of Medicine, University of Calgary, 2500 University Drive NW, Calgary, AB T2N 1N4, Canada. E-mail: tnaberan@ucalgary.ca

The study examined whether children who bully others are likely to prefer playing video games that are rated high in maturity and violence. A stratified random sample of Canadian children ages 10 to 17 years from the provinces of Canada was obtained. Parents $(n=397)$ and their children $(n=492)$ completed an online survey of children's bullying behaviors and their three favorite video games. Ordinal logistic regression analyses showed that parents' and children's reports of child preferences for mature and violent video games were significantly related to children's perpetration of bullying and cyberbullying. Panel regression analyses revealed no 
significant difference between parent and child informants. Children who play highly violent and mature video games were likely to bully and cyberbully their peers, according to both parent and child reports.

KEYWORDS bullying, cyberbullying, video game maturity, video game violence, parent and child reports

Bullying is now recognized as a significant social problem worldwide. Across 40 countries, Craig and colleagues (2009) found that $10.7 \%$ of adolescents (aged 11-15 years) reported bullying others, $12.6 \%$ report being bullied, and 3.6\% report both bullying others and being bullied. This behavior can take a variety of forms and involve varying methods, with the most recent being identified as cyberbullying involving bullying using a communication device such as a cell phone (Beran \& Li, 2007; Mishna, Beran, Poole, Gadalla, \& Daciuk, 2011; Wade \& Beran, 2011). Prevalence rates vary with approximately 11 to $17 \%$ of children cyberbullying others (Beran \& Li, 2005, 2007; Li, 2006, 2007; Patchin \& Hinduja, 2006). Given these high rates, as well as the evidence of negative consequences associated with bullying (Beran, Hughes, \& Lupart, 2008, Beran, Mishna, Hetherington, \& Shaheen, 2011; Hawker \& Boulton, 2000), it is important to study risk factors for bullying. Playing video games, particularly those games involving violence, is a well-known correlate of aggression (Anderson, 2010a, 2010b). Less is known, however, about video gaming in relation to bullying. The purpose of the current study was to investigate the relationship between children's (aged 10 to 17 years) video game preferences and their perpetration of bullying and cyberbullying, utilizing both parent and child reports.

\section{ACCEPTED MANUSCRIPT}




\section{Bullying}

Bullying is a unique form of interpersonal aggression. It involves intentionality from the perpetrator to harm someone perceived as having less power (Olweus, 2010). Pepler, Craig, Jiang, and Connolly (2008) describe the perpetration of bullying as a relationship problem whereby children learn to use power and aggression to cause distress for others and control them. Within Canada and the United States, approximately $22 \%$ of boys and $16 \%$ of girls report bullying others in one or more ways: physical (e.g., hitting), verbal (e.g., name calling), social (e.g., gossiping), racial (e.g., ethnic name calling), sexual (e.g., comments and actions), and cyber (e.g., using a communication device; Craig et al., 2009; Craig \& Harel, 2004; Pepler, Craig, Ziegler, \& Charach, 1993; Wang, Iannotti, \& Nansel, 2009). These perpetrating behaviors harm targeted children's cognitive, emotional, and psychological development (Gini \& Pozzoli, 2009; Kaltiala-Heino, Rimpela, Rantanen, \& Rimpela, 2000).

Cyberbullying has been defined inconsistently in the research (Menesini \& Nocentini, 2009; Patchin \& Hinduja, 2006). On the one hand, some researchers suggest cyberbullying is a unique form of bullying, alongside other forms of face-to-face bullying such as physical, verbal, and social bullying (Wade \& Beran, 2011; Dooley, Pyzalski, \& Cross, 2009; Vaillancourt et al., 2010; Wang et al., 2009). Other researchers suggest that it is simply a new medium through which traditional bullying can be inflicted (Campbell, 2005; Menesini \& Nocentini, 2009). Both perspectives suggest that all these types need to be measured. Cyberbullying involves the perpetrator sending embarrassing and/or hurtful messages in the form of email, text, or pictures through communications devices such as cell phones, laptops, and desk computers (Patchin \&

\section{ACCEPTED MANUSCRIPT}


Hinduja, 2006; Ybarra \& Mitchell, 2004). Some definitions suggest the aggressive behavior must be repetitive (Patchin \& Hinduja, 2006), whereas others suggest that it can involve a single act, given that a single act can be circulated widely or copied by others (Menesini \& Nocentini, 2009; Vandebosch \& Van Cleemput, 2008). The power differential between the perpetrator and victimized individuals remains an important criterion; however, this power difference may involve technological proficiency rather than physical strength or popularity (Patchin \& Hinduja, 2006; Vandebosch \& Van Cleemput, 2008). Involvement in cyberbullying has negative consequences for the mental health of youth, over and above traditional bullying (Blais, 2008). In the present study, we adopted the definition of cyberbullying as at least one act of aggression directed through a communications device against someone with less power than the perpetrator.

\section{Video Games}

Video games are one of the most popular pastimes for children in Western society. They can be played on video gaming systems, as well as most communication devices, making them accessible virtually anywhere an electronic device can be operated (Anderson, Gentile, \& Dill, 2012). A recent nationally representative study in the United States found that children ages 8 to 18 years-of-age play video games approximately 1 hour and 15 minutes per day with at least $60 \%$ of children playing on a given day (Rideout, Foehr, \& Roberts, 2010). These authors report a variety of games played by children, some with high levels of violent and mature content (Rideout et al., 2010).

The various video games available are rated for their "proper age category" or maturity level required to play and indicate the explicit content, including violence, in the games (Gentile, 
Humphrey, \& Walsh, 2005). The Entertainment Software Rating Board (ESRB) was developed by the Interactive Digital Software Association (IDSA) in an attempt to classify games into ageappropriate categories (similar to movie ratings; ESRB, 2012). Descriptions of maturity level indicate the presence of violence, sex, explicit language, and drug use in each game (Gentile et al., 2005). In addition, violence ratings identify the type of violence such as cartoon or fantasy violence in each game. Thompson and colleagues (Haninger, Ryan, \& Thompson, 2004; Haninger \& Thompson, 2004; Thompson, Tepichin, \& Haninger, 2006) suggest that a majority of video games contain violence. Recent research has suggested that nearly half of youth (49\%) play at least one video game rated as mature on a regular basis (Olson et al., 2007). In fact, some research suggests that the more mature the game rating, the more attractive the games are for youth, often entitled the "forbidden fruits" effect (Bijvank, Konjin, Bushman, \& Roelofsma, 2008).

\section{Video Games and Aggression}

There exists a multitude of studies on the relationship between video games and aggressive cognitions, attitudes, and behaviors (Gentile, Lynch, Linder, \& Walsh, 2004), with recent reviews (Bartlett, Anderson \& Swing, 2009; Ferguson, 2009) and meta-analyses (Anderson et al., 2010a, 2010b; Ferguson, 2007; Ferguson \& Kilburn, 2009) providing conflicting results (Bushman, Rothstein, \& Anderson, 2010; Ferguson \& Kilburn, 2010; Huesmann, 2010). The research community is "sharply divided" as to whether violent video games are harmful to children (Olson, 2004). The correlational, experimental, and longitudinal research suggests that aggression may be a consequence of playing violent video games (socialization hypothesis), an

\section{ACCEPTED MANUSCRIPT}


expression of traits that existed prior to playing violent video games (selection hypothesis), or some combination of the two (Anderson, Gentile, \& Buckley, 2007; Porter \& Starcevic, 2007). Recently, Willoughby, Adachi, and Good (2012) investigated both of these hypotheses longitudinally with a sample of high school students, finding strong support only for the socialization hypothesis and not the selection hypothesis, suggesting that video game play may lead to aggression over time.

Violent video games may have short-term and long-term influences on aggression. In the shortterm, they may serve as a situation variable that increases a child's aggressive thoughts, affect, and/or arousal, leading to aggressive behavior. In the long-term, they may invoke aggressive beliefs, attitudes, schemas, behavioral scripts, and expectations, as well as desensitization to aggression, which may promote aggression (Anderson \& Bushman, 2002; Carnagey \& Anderson, 2004; Huesmann, 2007). Willoughby and colleagues (2012) indicate that this theory suggests: "Each violent video game episode may reinforce the notion that aggression is an effective and appropriate way to deal with conflict and anger" (p. 2).

It is possible that video games may lead to various types of aggression, including bullying (Olson, 2004). Indeed, several researchers agree that violent video games are likely to have a stronger impact on non-criminal or less physically aggressive behaviors, such as bullying (Anderson et al., 2010; Ferguson \& Kilburn, 2010). Although some recent studies have examined the relationship between video games and bullying, cyberbullying has yet to be included. Ferguson and colleagues (Ferguson, 2011; Ferguson, Miguel, \& Hartly, 2009) have found significant but weak relationships between level of violence in videogames and bullying 
perpetration; however, these samples were not representative of the more general population and utilized samples of convenience (non-random). Whereas, Olson and colleagues (Ferguson, Olson, Kutner, \& Warner, 2010; Olson et al., 2009) have not found relationships between video game maturity level and bullying perpetration, even with a more representative sample of American students in grades seven and eight (Ferguson et al., 2010). Clearly, research in this area needs to be informed by large representative samples to determine whether game violence and maturity are indeed related to bullying.

There is currently a limited understanding of how children's video gaming behaviors may be related to their bullying behaviors. Furthermore, there are discrepant findings on the relationship between aggression and bullying perpetration, and there is no published research on video games in relation to cyberbullying. The current study examined whether there was a link between video gaming and cyberbullying perpetration. The study design utilized multiple informants (parents and children) from a large Canadian nationally representative sample. Thus, this study explored the relationship between the perpetration of bullying and the preference for maturity and violence in video games among a nationally representative sample of Canadian children ages 10 to 17 years. Various types of perpetration, parents' and children's reports, and child gender and age differences were also examined to determine whether children who prefer mature and violent video games bully others (controlling for child gender and age). We hypothesized that those children who played mature and violent video games would be involved in bullying perpetration. 


\section{Method}

\section{Sample}

The sample consisted of 1,000 parents ( $n=720$ mothers, $n=280$ fathers, mean age $=43.0, S D=$ 9.9) and their children ages 10 to 17 years ( $n=487$ girls, $n=513$ boys, mean age $=13.6, S D=$ 2.3) from all 10 provinces of Canada randomly selected (using simple random sampling) from a stratified national household sample managed by a Canadian research company. This household sample had been obtained from government census data to ensure representation of the population based on several demographic characteristics such as geographic location, age, and family size. They had also agreed to be contacted for research purposes. Parents of children within the age group (10 to 17 year-olds) in the household sample were randomly selected and contacted by email to request consent for themselves and one of their children to answer our online survey. The consent rate was $96.3 \%$. The majority of the families lived in urban areas (72.8\% urban, $27.2 \%$ rural), and the majority of the children were born in Canada (89.9\%). English was the most common language spoken at home (75\%), followed by French (20\%) and then other languages $(5 \%)$. The demographic characteristics of the sample are representative of children living in Canada (Statistics Canada, 2006). The current study reports on a sub-sample of participants who reported on children's video game preferences; only 397 parents $\quad(n=292$ mothers, $n=105$ fathers, mean age $=41.4, S D=9.4)$ and 432 children $(n=203$ girls, $n=229$ boys, mean age $=13.2, S D=2.2$ ) reported on video game preferences and thus, met the inclusion criteria.

\section{ACCEPTED MANUSCRIPT}




\section{Procedure}

Parents were provided with a consent form that indicated they were to complete the survey about one of their children between the ages of 10 and 17 ; they were to think of only that child when answering the subsequent questions. If they had more than one child within that age group, they were asked to select their youngest child. Following consent, electronic administration began automatically. Parents completed the questionnaire, which included demographic questions and questions related to the specific child's involvement in bullying and video games. Then they were instructed to invite that son or daughter (the person about whom they considered when answering the questions) to complete the next set of questions independently. The parental consent rate was $96.2 \%$ (any responses from parents whose child did not participate were removed from the analyses). The children were then provided with the purpose and terms of the study and asked to give assent. All children who had received parental consent provided assent. They were then administered a questionnaire. Administration time of the entire survey was a mean of 21 minutes.

\section{Measures}

Bullying. Parents and children were provided with the following definition of bullying (Pepler et al., 1993) adapted from Olweus' questionnaire (1989):

There are lots of ways to hurt someone. A person who bullies wants to hurt the other person. A person who bullies does it because they can. They may be older, stronger, bigger, or have other students on their side. There are different kinds of bullying:

\section{ACCEPTED MANUSCRIPT}




\section{ACCEPTED MANUSCRIPT}

- $\quad$ Physical, for example, hitting, kicking, or spitting

- Verbal, for example, name-calling, mocking, or hurtful teasing

- Social, for example, leaving someone out, gossiping, or spreading rumors

- $\quad$ Electronic, for example, on Facebook, email, or text messaging

- Racial, for example, saying hurtful things about someone whose skin is a different color

- Sexual, for example, kissing, grabbing, or saying something sexual

- $\quad$ Sexual preference, teasing someone for being gay whether they are or not

Students were provided with the above definition, which included the essential components (e.g., power differential) of bullying and no additional questions were asked assessing these criteria. After the definition was provided, participants were asked one question about whether they had bullied others during the last month (referred to as general bullying because it did not address any particular type) and then seven follow-up questions about the type they perpetrated: cyber, verbal, social, physical, racial, sexual comments, or sexual bullying. Responses to all of these bullying questions were rated on a 5-point scale: no, once or twice, 2 or 3 times a month, about once a week, and several times a week, with higher scores reflecting a higher frequency of involvement. Due to a relatively small number of responses indicating once a week or several times a week, scores were recoded on a 3 -point scale: $1=$ no, $2=$ once or twice, and $3=$ more than 2 times a month (a combination of " 2 or 3 times a month," "about once a week," and "several times a week"). Coefficient alpha of the seven types of perpetration was .82 for parent reports and .86 for child reports, indicating good inter-item reliability. 
Video games. Participants responded to an open-ended question asking them to name the children's three favorite video games. This question has been reported as a standard method for assessing video gaming behavior (Anderson \& Dill, 2000; Ferguson, 2011; Gentile et al., 2009). Video games were coded for maturity level and violence using coding schemes developed by Huesmann and colleagues and adapted from the ESRB (Gentile et al., 2005, 2009; Huesmann, Moise, Podolski, \& Eron, 2003). The maturity categories used from the ESRB include: early childhood (ages 3 years and older), everyone (ages 6 years and older), everyone $10+$ (ages 10 years and older), teen (ages 13 years and older), mature (ages 17 years and older), and adults only (not intended for children under the age of 18 years). Values ranged from 1 to 6 with higher scores indicating higher maturity. A high correlation has been reported between student ratings of maturity with expert ratings ( $r=.75, p<.001$; Gentile et al., 2009), demonstrating good concurrent validity. Violence was coded with the modified ESRB content descriptors (i.e., $1=$ no mention of violence, $2=$ cartoon violence or mild animated violence, $3=$ mild violence, fantasy or animated violence, or $4=$ violence). Higher ratings indicated more violence. Content validity is demonstrated by basing the coding on the ESRB ratings, ratings of which are assigned through a consensus of three experts with familiarity of video games (ESRB, 2012).

The majority of video games were included in the ratings given by the ESRB (approximately $80 \%$ of all reported games). When codes were unavailable on the ESRB website or game itself, the researchers viewed or played the games. Researchers independently reviewed the ESRB website, which contained information about what classified a game into a maturity category and about the content descriptors. The reviewers then viewed or played the game and examined the specific content to determine classification (e.g., explicit language, sex, drugs, violence). Names 
of video games given by parents and children that were vague (e.g., "action series"), or described a device or website (e.g., "Nintendo Wii" or "anything on ourworld.com") were not coded. Of the 583 different responses provided by parents and children, 59 could not be coded.

The mean score of the three video games was used as the maturity and violence scores. Two raters coded all video games. For parent ratings, the inter-rater reliability (intraclass correlation coefficients) were .95 for maturity and .91 for violence. For children's ratings, the interrater reliability (intraclass correlation coefficients) was .94 for maturity and .90 for violence, indicating good interrater reliability.

A total of 467 parents and 493 children did not answer the question about preferred video games. Perhaps they did not know the names of video games, the child may not have played video games, or other unknown reasons. In total, 397 parents and 432 children reported video games that could be coded, which formed the sample size in the analyses of video game maturity and violence. There were no significant differences in demographic characteristics or frequency of bullying between the samples that did, and did not, answer the question about video game preferences.

\section{Statistical Analyses}

Descriptive statistics were computed using the entire sample, and for boys and girls separately. Given the ordinal level of measurement of bullying, Spearman Rank correlations were computed to compare the similarity between parent and child reports of bullying, video game maturity and violence ratings. Differences in parent and child reports of preferences for

\section{ACCEPTED MANUSCRIPT}


video game maturity and violence were compared between boys and girls using Multivariate Analysis of Variance (MANOVA). Also, gender differences in the bullying responses, as measured by the three-point response scales, were analyzed with Mann-Whitney tests. Spearman Rank correlations were then calculated to determine if children's age, bullying, and video game maturity and violence were related. Ordinal logistic regression analyses were used to determine the relative importance of video game maturity and violence in relation to the various types of bullying perpetrated. Child gender and age, and general bullying perpetration were included in the regression along with their interaction effects. Finally, panel regression analyses were used to investigate informant effects, specifically differences between parent and child reports.

\section{Results}

\section{Descriptive Statistics}

The maturity and violence scores for the video games and the frequency of all types of bullying for the overall sample, as well as boys and girls separately, are shown in Table 1. The majority of games were rated at a level of everyone $10+$ and mild violence/realistic violence. Also, the frequency of each type of reported perpetration was low. The correlations between parent and child reported video game maturity and violence and all types of bullying perpetration are reported in Table 2. The concordance was high for video game maturity $(r=.83, p<.01)$ and violence $(r=.83, p<.01)$. Thus, parents and children generally agree on the types of video games children prefer. The level of correspondence for bullying perpetration was moderate, depending upon the form of bullying. Thus, in general, parents and children report relatively

\section{ACCEPTED MANUSCRIPT}


similar levels of child involvement in bullying perpetration. Table 2 shows the correlations of the types of bullying perpetration with the maturity and violent content of video games. The correlations with the highest magnitude and largest number of significance values were for cyberbullying. This type and general bullying (as an estimate of various forms of perpetration) were used in subsequent analyses.

Table 3 presents correlations separated by gender. MANOVA analyses showed significant gender differences for both parent and child reports of video game preferences. Parents reported higher levels of video game maturity and violence for their sons $(M=3.25, S D=0.84, M=2.20$, $S D=1.20$, respectively) than for their daughters $(M=2.64, S D=0.75, M=1.22, S D=1.22$, respectively), Wilks' Lambda $=.86, F(2,394)=33.29 p<.001$, partial eta ${ }^{2}=.15$. Similar results were found for children's reports, with boys preferring games with higher ratings of maturity and violence $(M=3.41, S D=0.82, M=2.30, S D=1.22$, respectively), than $\operatorname{did}$ girls $(M=2.67, S D$ $=0.77, M=1.15, S D=1.18$, respectively $)$ Wilks' Lambda $=.80, F(2,429)=54.12, p<.001$, partial eta $^{2}=.20$. Mann-Whitney tests showed significant gender differences for parent reports of general bullying (Mann-Whitney $U=119034.00, \mathrm{p}<.05$ ), verbal bullying (Mann-Whitney $U=$ $118381.00, p<.05$ ), and physical bullying (Mann-Whitney $U=119694.00, p<.05$ ) with parents reporting higher levels of these types of bullying for boys than for girls. Gender differences were also found for child reports of general bullying (Mann-Whitney $U=116160.00, p<.05$ ), cyberbullying (Mann-Whitney $U=120335.50, p<.05$ ), verbal bullying (Mann-Whitney $U=$ $116659.50, p<.05$ ), and physical bullying (Mann-Whitney $U=119813.50, p<.05$ ), with boys reporting higher levels than girls for all of these types. Spearman's Rank Order correlations indicated that children's age was significantly related to parent ratings of maturity $(r=.24)$ and

\section{ACCEPTED MANUSCRIPT}


violence $(r=.22)$, and to children's ratings of maturity $(r=.20)$ and violence $(r=.18), p<.001$. Regarding age and bullying perpetration, no correlations were significant, $p>.05$.

A total of four ordinal logistic regression analyses were completed for parent and child reports of video game maturity and violence with bullying perpetration (Table 4). Ordinal logistic regression was also used instead of multiple or logistic regression because ordinal logistic regression can account for the skewness of the bullying perpetration data and include any possible important differences between the different perpetration groups (i.e., once or twice a month versus more than two times per month). First, an ordinal logistic regression of parent reports of video game maturity and violence with general bullying perpetration was completed. That is, general bullying, as well as child gender and age, were entered in the regression. Next, maturity and violence levels were entered to determine if they explained additional variance and improved model fit. Finally, interaction terms related to child gender and video game maturity and violence were included to identify any interaction effects. Child gender explained a significant amount of variance in general bullying perpetration, yet no significant interaction effects were found. A significant change in model fit (log likelihood) was obtained when video game maturity and violence were used to predict bullying perpetration. A similar procedure was used for child reports of video game maturity and violence and general bullying perpetration. Child gender explained a significant amount of variance in children's reports of general bullying perpetration; however, again, no significant child gender interaction effects were found. This analysis yielded significant change in model fit (log likelihood) when video game maturity and violence were entered with a significant impact of video game violence, suggesting that video

\section{ACCEPTED MANUSCRIPT}


game maturity and violence were significantly associated with children's reports of general bullying perpetration.

The second set of ordinal logistic regression analyses were completed to determine which of the parent and child reports of video game maturity and violence were most closely related to cyberbullying perpetration. For parent reports, child gender and age were entered first into an ordinal logistic regression with general bullying also entered in these analyses as a control. Next, maturity and violence levels were entered, followed by interaction terms for child gender and video game maturity and violence. A similar procedure was followed for child reports of video game maturity and violence. As shown in Table 4, general bullying explained a significant amount of variance in cyberbullying perpetration, according to parent and child reports. Using both of these report sources, a significant change in model fit (log likelihood) was obtained when video game maturity and violence were entered. In sum, general bullying, and video game maturity and violence were significantly associated with cyberbullying perpetration.

A panel regression utilizing a mixed model format was completed to investigate any informant effects. The data were recoded in long format with informant (child $=$ informant 1 and parent $=$ informant 2) as the identifying variable. A panel regression was completed investigating informant effects of gender, age, maturity, and violence on general bullying perpetration. No informant effects were found, Wald $x^{2}(1)=0.08, p>.05$. A similar panel regression was completed investigating informant effects of gender, age, maturity, and violence on cyberbullying perpetration. Similarly, no informant effects were found, Wald $x^{2}(1)=0.01, p>.05$.

\section{ACCEPTED MANUSCRIPT}




\section{Discussion}

The current study extends the literature by determining that children who perpetrate cyberbullying are likely to prefer mature and violent video games. These results were found for both parent and child reports from a stratified nationally representative Canadian sample. This study also showed that parents and children generally agree on the maturity level and violence of video games children play. Parents and children agreed that boys and older children play more violent and mature video games than girls and younger children. These results are consistent with the literature, with boys and older children more likely to be attracted to games with higher maturity ratings than girls and younger children (Bijvank et al., 2008). Parents and children tended to agreed on levels of bullying perpetration. Both parents and children reported that boys perpetrated more general, physical, and verbal bullying than girls. These results are consistent with the majority of bullying studies that report boys are more likely to engage in bullying than girls, particularly physical and verbal bullying (Craig et al., 2009; Craig \& McCuaig Edge, 2012; Hong \& Espelage, 2012; Olweus, 2010). Children, but not parents, reported that boys engage in more cyberbullying than girls. Gender differences in cyberbullying have been inconsistent in the literature, with several studies reporting the involvement of more girls than boys (Beran \& $\mathrm{Li}$, 2005; Li, 2007; Wade \& Beran, 2011), some studies finding boys more often involved than girls (Li, 2006), and other studies reporting no gender differences (Slonje \& Smith, 2008).

Both general bullying and cyberbullying were related to preferences for playing mature and violent video games, based upon both the parents' and children's perspectives. In fact, cyberbullying was related to mature and violent video games even after general bullying was

\section{ACCEPTED MANUSCRIPT}


taken into account. It is unclear whether bullying and/or cyberbullying are a consequence of mature and violent video games (socialization hypothesis) or that those individuals who bully and/or cyberbully select more mature and violent video games due to a pre-existing trait, such as hostility (selection hypothesis). What is clear is that cyberbullying and mature and violent video games share a similar medium through communication devices. These methods are convenient for asserting pre-existing or consequential aggression (Huesmann, 2007), and allow immediate transfer of aggression with "just the click of a button." This instant expression of aggression may allow youth to use cyberbullying as a means of expressing anger and managing conflict that may be exacerbated and/or instigated by playing mature and violent video games. It is also possible that these games teach and repeat derogatory terms and behaviors that children then use against their peers.

During the 20th and 21 st centuries, one of the largest changes, for better and for worse, has been the immersion of the mass media in our culture and daily lives. Technology, through the use of communication devices, the Internet, and video games, has become central to children's leisure activities, influencing their values, beliefs, and behaviors (Huesmann, 2007; Rideout et al., 2010). As suggested by Huesmann (2007), this increase in technology may lead to an increased use of video games and communication devices that provide new venues for youth to assert aggression.

\section{Limitations}

There are several limitations. First, although the study utilized a representative sample of all the Canadian provinces, no children were sampled from the northern territories, the 
participants had agreed to be contacted for research purposes, and had to have email access. Second, children and parents may have been reluctant to report aggressive bullying and violent video game preferences due to a social desirability effect. Third, although parents and children were instructed to complete the questions independently, there is no way to determine if they did. Fourth, this study did not define the repetitive nature of bullying nor did it assess the amount of time children spent online playing these video games, the nature of the video game play, and the level of access children have to technology (i.e., for cyberbullying or playing video games). Finally, the study was cross-sectional in nature so causality cannot be assumed. It is possible that, as described in the debate on video games and aggression, a child who bullies and cyberbullies others is drawn to more mature and violent video games than his/her peers who do not bully and cyberbully others.

\section{Research Implications}

Future research can employ qualitative methods such as interviewing parents and children who believe the child is playing mature and violent video games as well as bullying others. Their perceptions may provide insights into why children may be involved in both. Quantitative research on the relationship between video games and aggression may provide some insight into these reasons, suggesting the socialization and/or selection hypotheses (Porter \& Starcevic, 2007; Willoughby et al., 2012). Qualitative research would provide an opportunity to examine these hypotheses in more depth and identify whether they also apply to the relationship between bullying and violent and mature video games. Access to and time spent online and playing video games as well as the nature of the video game play and cyberbullying are also important to 
further understand. For example, perhaps those children who spend considerable time playing such games are most likely to bully others who are also playing these games simultaneously. The nature of the relationship between the perpetrator and bullied child in other settings may also shed light into why bullying is related to video game preferences. Longitudinal research is also needed to determine whether video game preferences or bullying precedes the other.

\section{Practice and Policy Implications}

Researchers who study the effects of bullying and video games have been advocating for ways to protect children. Although bullying interventions are occurring in schools (Beran \& Li, 2007; Beran et al., 2008), a culture change is needed that shifts beliefs and behaviors related to bullying (Williams \& Guerra, 2007). Parents can monitor both their children's on-line communication and gaming behaviors by becoming familiar with the devices children use, limiting access, and requiring that passwords be shared with them when such devices are given to their children. They can also enforce rules about computers and mobile devices being kept in public areas of the home, setting time limits, using filters or protection software, and encouraging alternate activities (Campbell, 2005). Perhaps of utmost importance is the need to promote healthy relationships between children and their parents, as well as children and their peers, which support nonviolence and respect.

\section{STATEMENT ON FUNDING}

Standard Research Grant \#410-2007-0671 from the Social Sciences and Humanities Research Council of Canada supported this research.

\section{ACCEPTED MANUSCRIPT}




\section{COMPETING INTERESTS}

There are none.

\section{REFERENCES}

Anderson, C. A. (2010a). Violent video games and other media violence (part I). Pediatrics for Parents, 26(1/2), 28-30.

Anderson, C. A. (2010b). Violent video games and other media violence (part II). Pediatrics for Parents, 26(3/4), 21-23.

Anderson, C. A., \& Bushman, B. J. (2002). Human aggression. Annual Review of Psychology, 53, 27-51. doi:10.1146/annurev.psych.53.100901.135231

Anderson, C. A., \& Dill, K. E. (2000). Video games and aggressive thoughts, feelings, and behavior in the laboratory and in life. Journal of Personality \& Social Psychology, 78, 772-791. doi:10.1037//0022-3514.78.4.772

Anderson, C. A., Gentile, D. A., \& Buckley, K. E. (2006). Violent video game effects on children and adolescents: Theory, research, and public policy. New York, NY: Oxford University Press. doi:10.1093/acprof:oso/9780195309836.001.0001

Anderson, C. A., Gentile, D. A., \& Dill, K. E. (2012). Prosocial, antisocial, and other effects of recreational video games. In D. G. Singer \& J. L. Singer (Eds.), Handbook of children and the media ( $2^{\text {nd }}$ ed., pp. 249-272). Thousand Oaks, CA: Sage.

\section{ACCEPTED MANUSCRIPT}


Anderson, C. A., Shibuya, A., Ihori, N., Swing, E. L., Bushman, B. J., Sakamoto, A., et al. (2010). Violent video game effects on aggression, empathy, and prosocial behavior in Eastern and Western countries: A meta-analytic review. Psychological Bulletin, 136, 151-173. doi:10.1037/a0018251

Bartlett, C. P., Anderson, C. A., \& Swing, E. L. (2009). Video game effects-Confirmed, suspected, and speculative: A review of the evidence. Simulation \& Gaming, 40, 377-403. doi:10.1177/1046878108327539

Beran, T., \& Hughes, G., \& Lupart, J. (2008). A model of achievement and bullying: Analyses of the Canadian National Longitudinal Survey of Children and Youth data. Educational Research, 50(1), 25-39. doi:10.1080/00131880801920379

Beran, T. N., Mishna, F., Hetherington, R., \& Shaheen, S. (2011). Children's experiences of cyber bullying: A Canadian national study. Unpublished manuscript.

Beran, T., \& Li, Q. (2005). Cyber-harassment: A study of a new method for an old behaviour. Journal of Educational Computing Research, 32, 265-277. doi:10.2190/8YQM-B04H-PG4DBLLH

Beran, T., \& Li, Q. (2007). The relationship between cyberbullying and school bullying. Journal of Student Wellbeing, 1(2), 15-33. Retrieved from http://www.ojs.unisa.edu.au/index.php/ JSW

Bijvank, M. N., Konijn, E. A., B. J., \& Roelofsma, P. H. M. P. (2008). Age and violent-content labels make video games forbidden fruits for youth. Pediatrics, 123, 870-876. doi:10.1542/peds.2008-060

\section{ACCEPTED MANUSCRIPT}


Blais, J. (2008). Chatting, befriending, and bullying: Adolescents' Internet experiences and associated psychosocial outcomes (Unpublished doctoral dissertation). Queen's University, Kingston, Ontario.

Bushman, B. J., Rothstein, H. R., \& Anderson, C. A. (2010). Much ado about something. Violent video game effects and a school of red herring: Reply to Ferguson and Kilburn (2010). Psychological Bulletin, 136, 182-187. doi:10.1037/a0018718

Campbell, M. A. (2005). Cyber bullying: An old problem in a new guise. Australian Journal of Guidance \& Counselling, 15, 68-76. doi:10.1375/ajgc.15.1.68

Carnagey, N. I., \& Anderson, C. A. (2004). Violent video game exposure and aggression: A literature review. Minerva Psichiatrica, 45, 1-18.

Craig, W. M., \& Harel, Y. (2004). Bullying, physical fighting and victimization. In C. Currie, C. Roberts, A. Morgan, R. Smith, W. Settertobulte, O. Samdal, et al. (Eds.), Health policy for children and adolescents, No. 4. Young people's health in context: Health behavior in schoolaged children (HBSC) study: international report from the 2001/2002 survey (pp. 133-144). Copenhagen, Denmark: World Health Organization.

Craig, W., Harel-Fisch, Y., Fogel-Grinvald, H., Dostaler, S., Hetland, J., Simons-Morton, B., et al. (2009). A cross-national profile of bullying and victimization among adolescents in 40 countries. International Journal of Public Health, 54, 216-224. doi:10.1007/s00038-009-5413-9

Craig, C., \& McCuaig Edge, H. (2008). Bullying and fighting. In J. G. Freeman, M. King, W. Pickett, W. Craig, F. Elgar, I. Janssen, \& D. Klinger (Eds.), The health of Canada's young people: A mental health focus (pp. 167-183). Ottawa, ON: Public Health Agency of Canada. 
Dooley, J. J., Pyzalski, J., \& Cross, D. (2009). Cyberbullying versus face-to-face bullying: A theoretical and conceptual review. Zeitschrift fur Psychologie / Journal of Psychology, 217, 182188. doi:10.1027/0044-3409.217.4.182

Entertainment Software Rating Board. (2012). ESRB Ratings. Retrieved from http://www.esrb.org/ratings/index.jsp

Ferguson, C. J. (2007). The good, the bad, and the ugly: A meta-analytic review of positive and negative effects of violent video games. Psychiatric Quarterly, 78, 309-316. doi:10.1007/s11126-007-9056-9

Ferguson, C. J. (2009). Research on the effects of violent video games: A critical analysis. Social and Personality Psychology Compass, 3, 351-364. doi:10.1111/j.1751-9004.2009. 00175.x

Ferguson, C. J. (2011). Video games and youth violence: A prospective analysis in adolescents. Journal of Youth and Adolescence, 40, 377-391. doi:10.1007/s10964-010-9610-x

Ferguson, C. J., \& Kilburn, J. (2009). The public health risks of media violence: A meta-analytic review. Journal of Pediatrics, 154, 759-763. doi:10.1016/j.jpeds.2008.11.033

Ferguson, C. J., \& Kilburn, J. (2010). Much ado about nothing: The misestimation and overinterpretation of violent video game effects in Eastern and Western nations: Comment on Anderson et al. (2010). Psychological Bulletin, 136, 174-178. doi: 10.1037/a0018566

Ferguson, C. J., Miguel, C. S., \& Hartley, R. D. (2009). A multivariate analysis of youth violence and aggression: The influence of family, peers, depression, and media violence. The Journal of Pediatrics, 6, 904-908. doi:10.1016/j.jpeds.2009.06.021

\section{ACCEPTED MANUSCRIPT}


Ferguson, C. J., Olson, C. K., Kutner, L. A., \& Warner, D. E. (2010). Violent video games, catharsis seeking, bullying, and delinquency: A multivariate analysis of effects. Crime \& Delinquency. Advance online publication. doi:10.1177/0011128710362201

Gentile, D. A., Anderson, C. A., Yukawa, S., Ihori, N., Saleem, M., Ming, L. K., et al. (2009). The effects of prosocial video games on prosocial behaviors: International evidence from correlational, experimental, and longitudinal studies. Personality and Social Psychology Bulletin, 35, 752-763. doi:10.1177/0146167209333045

Gentile, D. A., Humphrey, J., \& Walsh, D. A. (2005). Media ratings for movies, music, video games, and television: A review of the research and recommendations for improvements. Adolescent Medicine Clinics, 16, 427-446. doi:10.1016/j.admecli.2005.02.006

Gentile, D. A., Lynch, P. J., Linder, J. R., \& Walsh, D. A. (2004). The effects of violent video game habits on adolescent hostility, aggressive behaviors, and school performance. Journal of Adolescence, 27, 5-22. doi:10.1016/j.adolescence.2003.10.002

Gini, G., \& Pozzoli, T. (2009). Association between bullying and psychosomatic problems: A meta-analysis. Pediatrics, 123, 1059-1065. doi:10.1542/peds.2008-1215

Haninger, K., Ryan, S., \& Thompson, K., M. (2004). Violence in teen-rated video games. Medscape General Medicine, 6(1). Retrieved from http://www.ncbi.nlm.nih.gov/pmc/ articles/ PMC1140725/

Haninger, K. M., \& Thompson, K. M. (2004). Content and ratings of teen-rated video games. Journal of American Medical Association, 291, 856-865. doi:10.1001/jama.291.7.856

\section{ACCEPTED MANUSCRIPT}


Hawker, D. S. J., \& Boulton, M. J. (2000). Twenty years' research on peer victimization and psychosocial maladjustment: A meta-analytic review of cross-sectional studies. Journal of Child Psychology and Psychiatry, 41, 441-455. doi:10.1111/1469-7610.00629

Hong, J. S., \& Espelage, D. L. (2012). A review of research on bullying and peer victimization in school: An ecological system analysis. Aggression and Violent Behavior, 17, 311-322. doi:10.1016/j.avb.2012.03.003

Huesmann, L. R. (2007). The impact of electronic media violence: Scientific theory and research. Journal of Adolescent Health, 41, S6-S13. doi:10.1016/j.jadohealth.2007.09 .005

Huesmann, L. R. (2010). Nailing the coffin shut on doubts that violent games stimulate aggression: Comment on Anderson et al. (2010). Psychological Bulletin, 136, 179-181. doi:10.1037/a0018567

Huesmann, L. R., Moise, J., Podolski, C. P., \& Eron, L. D. (2003). Longitudinal relations between childhood exposure to media violence and adult aggression and violence: 1977-1992. Developmental Psychology, 39, 201-221. doi:10.1037//0012-1649.39.2.201

Kaltiala-Heino, R., Rimpela, M., Rantanen, P., \& Rimpela, A. (2000). Bullying at school-An indicator of adolescents at risk for mental disorders. Journal of Adolescence, 23, 661-674. doi:10.1006//jado.2000.0351

Li, Q. (2006). Cyberbullying in schools: A research of gender differences. School Psychology International, 27, 157-170. doi:10.1177/0143034306064547

Li, Q. (2007). New bottle but old wine: A research of cyber bullying in schools. Computers in Human Behavior, 23, 1777-1791. doi:10.1016/j.chb.2005.10.005 
Menesini, E., \& Nocentini, A. (2009). Cyberbullying definition and measurement. Journal of Psychology, 217, 230-232. doi:10.1027/0044-3409.217.4.230

Mishna, F., Beran, T. N., Poole, A., Gadalla, T., \& Daciuk, J. (2011). The cyber world and cyber bullying: Differences between children and parents. In D. Pepler, J. Cummings, \& W. Craig (Eds.), Creating a world without bullying PREVNET Series (Vol. 3, pp. 101-111). Ottawa, ON: National Printers.

Olson, C. K. (2004). Media violence research and youth violence data: Why do they conflict? Academic Psychiatry, 28, 144-150. doi:10.1176/appi.ap.28.2.144

Olson, C. K., Kutner, L. A., Warner, D. E., Almerigi, J. B., Baer, L., Nicholi, A. M., \& Beresin, E. V. (2007). Factors correlated with violent video game use by adolescent boys and girls. Journal of Adolescent Health, 41, 77-83. doi:10.1016/j.jadohealth.2007.01.001

Olson, C. K., Kutner, L. A., Baer, L., Beresin, E. V., Warner, D. E., \& Nicholi, A. M. (2009). M$\underline{\text { rated video games and aggressive or problem behavior among young adolescents. Applied }}$ Developmental Science, 13, 188-198. doi:10.1080/10888690903288748

Olweus, D. (1989). Questionnaire for students (Junior and senior versions). Unpublished manuscript.

Olweus, D. (2010). Understanding and researching bullying: Some critical issues. In S. R. Jimerson, S. M. Swearer, \& D. L. Espelage (Eds.), The handbook of bullying in schools: An international perspective (pp. 9-33). New York, NY: Routledge.

\section{ACCEPTED MANUSCRIPT}


Patchin, J. W., \& Hinduja, S. (2006). Bullies move beyond the schoolyard: A preliminary look at cyberbullying. Youth Violence and Juvenile Justice 4, 148-169. doi:10.1177/1541204006 286288

Pepler, D. J., Craig, W. M., Jiang, D., \& Connolly, J. (2008). Developmental trajectories of bullying and association factors. Child Development, 79, 325-338. doi:10.1111/j.14678624.2007. 01128.x

Pepler, D. J., Craig, W. M., Ziegler, S., \& Charach, A. (1993). A school-based antibullying intervention: Preliminary evaluation. In D. Tattum (Ed.), Understanding and managing bullying (pp. 76-91). Portsmouth, NH: Heinemann.

Porter, G., \& Starcevic, V. (2007). Are violent video games harmful? Australian Psychiatry, 15, 422-426. doi:10.1080/10398560701463343

Rideout, V. J., Foehr, U. G., \& Roberts, D. F. (2010). Generation $M^{2}$ : Media lives of 8- to 18year-olds. A Kaiser family foundation study. Mento Park, CA: Kaiser Family Foundation.

Slonje, R., \& Smith, P. K. (2008). Cyberbullying: Another main type of bullying? Scandinavian Journal of Psychology, 49, 147-154. doi:10.1111/j.1467-9450.2007.00611.

Statistics Canada. (2006). Census data products. Retrieved October 20, 2010, from statcan.gc.ca Thompson, K. M., Tepichin, K., \& Haninger, K. (2006). Content and ratings of mature-rated video games. Archives of Pediatric \& Adolescent Medicine, 160, 402-410. doi:10.1001/ archpedi.160.4.402

\section{ACCEPTED MANUSCRIPT}


Vaillancourt, T., Trinh, V., McDougall, P., Duku, E., Cunningham, L., Cunningham, C., et al. (2010). Optimizing population screening of bullying in school-aged children. Journal of School Violence, 9, 233-250. doi:10.1080/15388220.2010.483182

Vandebosch, H., \& Van Cleemput, K. (2008). Defining cyberbullying: A qualitative research into the perceptions of youngsters. CyberPsychology \& Behavior, 11, 499-503. doi:10.1089/cpb.2007.0042

Wade, A., \& Beran, T. N. (2011). Cyberbullying: The new era of bullying. Canadian Journal of School Psychology, 26, 44-61. doi:10.1177/0829573510396318

Wang, J., Iannotti, R. J., \& Nansel, T. R. (2009). School bullying among adolescents in the United States: Physical, verbal, relational, and cyber. Journal of Adolescent Health, 45, 368-375. doi:10.1016/j.jadohealth.2009.03.021

Williams, K. R., \& Guerra, N. G. (2007). Prevalence and predictors of Internet bullying. Journal of Adolescent Health, 41, S14-S21. doi:10.1016/j.jadohealth.2007.08.018

Willoughby, T., Adachi, P. J. C., \& Good, M. (2012). A longitudinal study of the association between violent video game play and aggression among adolescents.Developmental Psychology, 48, 1044-1057. doi:10.1037/a0026046

Ybarra, M., \& Mitchell, K. (2004). Online aggressors/targets, aggressors, and targets: A comparison of associated youth characteristics. Journal of Child Psychology and Psychiatry, 45, 1308-1316. doi:10.1111/j.1469-7610.2004.00328.x 
Table 1 Descriptive Statistics of Video Game Preferences and Bullying Perpetration

\begin{tabular}{|c|c|c|c|c|c|c|c|c|c|c|c|c|}
\hline & \multicolumn{6}{|c|}{ Parent reports } & \multicolumn{6}{|c|}{ Child reports } \\
\hline & \multicolumn{2}{|c|}{ Overall } & \multicolumn{2}{|c|}{$\begin{array}{l}\text { Male } \\
\text { child }\end{array}$} & \multicolumn{2}{|c|}{$\begin{array}{l}\text { Female } \\
\text { child }\end{array}$} & \multicolumn{2}{|c|}{ Overall } & \multicolumn{2}{|c|}{$\begin{array}{l}\text { Male } \\
\text { child }\end{array}$} & \multicolumn{2}{|c|}{$\begin{array}{l}\text { Female } \\
\text { child }\end{array}$} \\
\hline & $M$ & $S D$ & $M$ & $S D$ & $M$ & $S D$ & $M$ & $S D$ & $M$ & $S D$ & $M$ & $S D$ \\
\hline $\begin{array}{l}\text { Video } \\
\text { game }\end{array}$ & \multicolumn{2}{|c|}{$N=397$} & \multicolumn{2}{|c|}{$n=211$} & \multicolumn{2}{|c|}{$n=186$} & \multicolumn{2}{|c|}{$n=432$} & \multicolumn{2}{|c|}{$n=229$} & \multicolumn{2}{|c|}{$n=203$} \\
\hline \multirow[t]{2}{*}{ Maturity } & 2.9 & 0.8 & 3.2 & .84 & 2.6 & .75 & 3.0 & 0.8 & 3.4 & .82 & 2.6 & .77 \\
\hline & 6 & 6 & 5 & & 4 & & 6 & 7 & 1 & & 7 & \\
\hline \multirow[t]{2}{*}{ Violence } & 1.7 & 1.3 & 2.2 & 1.2 & 1.2 & 1.2 & 1.7 & 1.3 & 2.3 & 1.2 & 1.1 & 1.1 \\
\hline & 5 & 1 & 0 & 0 & 3 & 2 & 6 & 3 & 0 & 2 & 5 & 8 \\
\hline $\begin{array}{l}\text { Bullying } \\
\text { perpetrati }\end{array}$ & \multicolumn{2}{|c|}{$N=1000$} & \multicolumn{2}{|c|}{$n=513$} & \multicolumn{2}{|c|}{$n=487$} & \multicolumn{2}{|c|}{$N=1000$} & \multicolumn{2}{|c|}{$n=513$} & \multicolumn{2}{|c|}{$n=487$} \\
\hline
\end{tabular}


General

$\begin{array}{llll}1.1 & .39 & 1.1 & .4\end{array}$

$1.1 \quad .36$

$1.1 \quad .44$

$1.2 \quad .47$

$1.1 \quad .39$

4

7

2

7

3

Cyber

$1.0 \quad .28$

$1.0 \quad .30$

$1.0 \quad .26$

$1.1 \quad .36$

$1.1 \quad .41$

$1.0 \quad .30$

6

7

5

0

3

7

Verbal

$\begin{array}{llll}1.1 & .38 & 1.1 & .45\end{array}$

$1.0 \quad .30$

$1.1 \quad .43$

$1.1 \quad .48$

$1.1 \quad .37$

2

$6 \quad 8$

5

9

0

Social

$\begin{array}{llll}1.0 & .25 & 1.0 & .25\end{array}$

$1.0 \quad .24$

$1.0 \quad .26$

$1.0 \quad .28$

$1.0 \quad .23$

4

5

4

5

6

5

Physical

$\begin{array}{llll}1.0 & .28 & 1.0 & .34\end{array}$

$1.0 \quad .19$

$1.0 \quad .32$

$1.1 \quad .37$

$1.0 \quad .26$

6

8

3

8

0

5

Racial

$\begin{array}{llll}1.0 & .21 & 1.0 & .24\end{array}$

$1.0 \quad .18$

$\begin{array}{ll}1.0 & .21\end{array}$

$1.0 \quad .24$

$1.0 \quad .19$

3

4

2

3

4

3

Sexual

$\begin{array}{llll}1.0 & .17 & 1.0 & .19\end{array}$

$1.0 \quad .16$

$1.0 \quad .18$

$1.0 \quad .21$

$\begin{array}{ll}1.0 & .15\end{array}$

comments 2

2

2

2

3

2

Sexual

$\begin{array}{llll}1.0 & .19 & 1.0 & .21\end{array}$

$1.0 \quad .17$

$1.0 \quad .17$

$\begin{array}{ll}1.0 & .17\end{array}$

$1.0 \quad .16$ 
ACCEPTED MANUSCRIPT

3

2

2

2

2 
Table 2 Spearman Correlations of Parent and Child Reports: Video Game Preferences and Bullying Perpetration

Parent reports

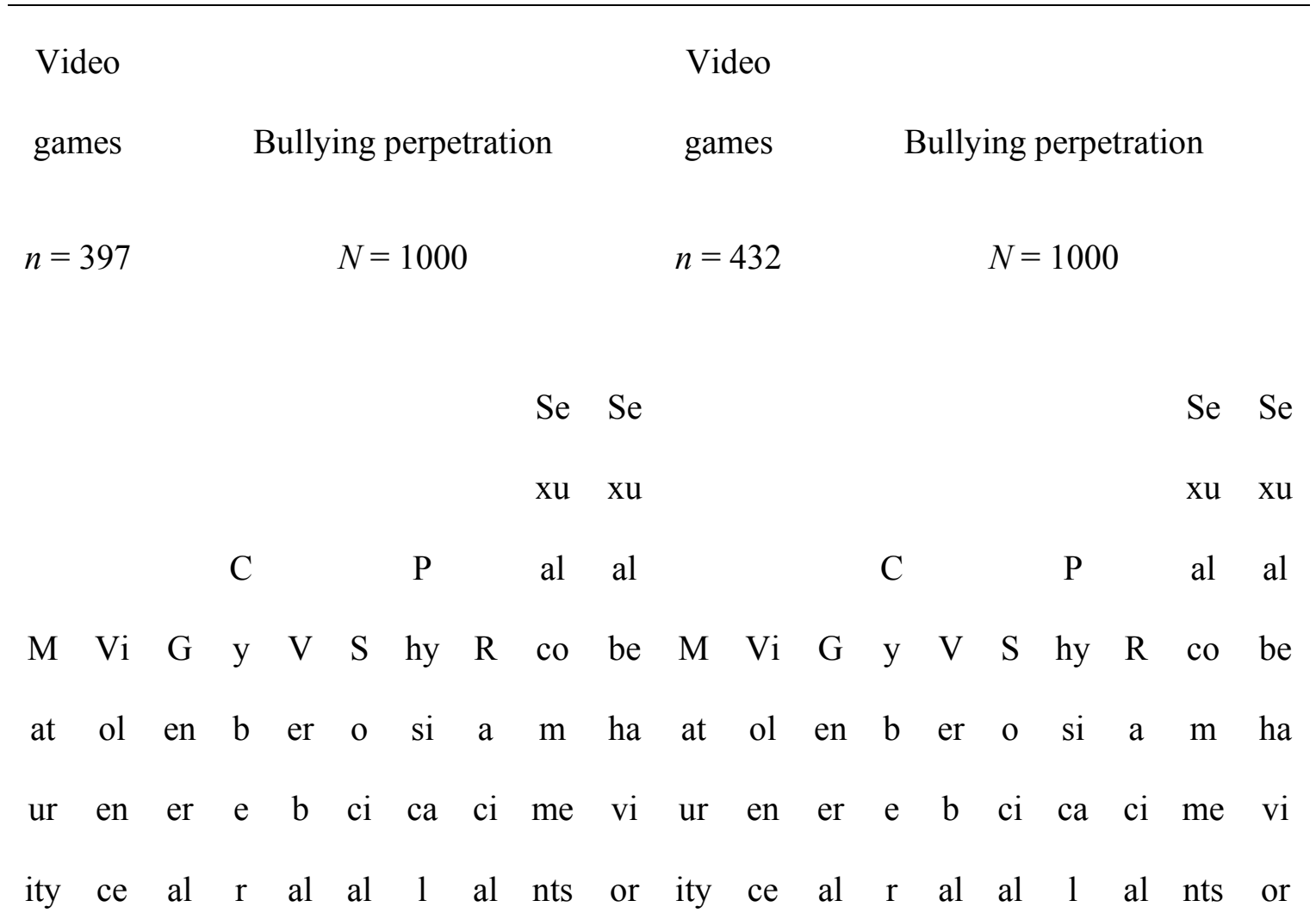

Par

ent

rep

ort 


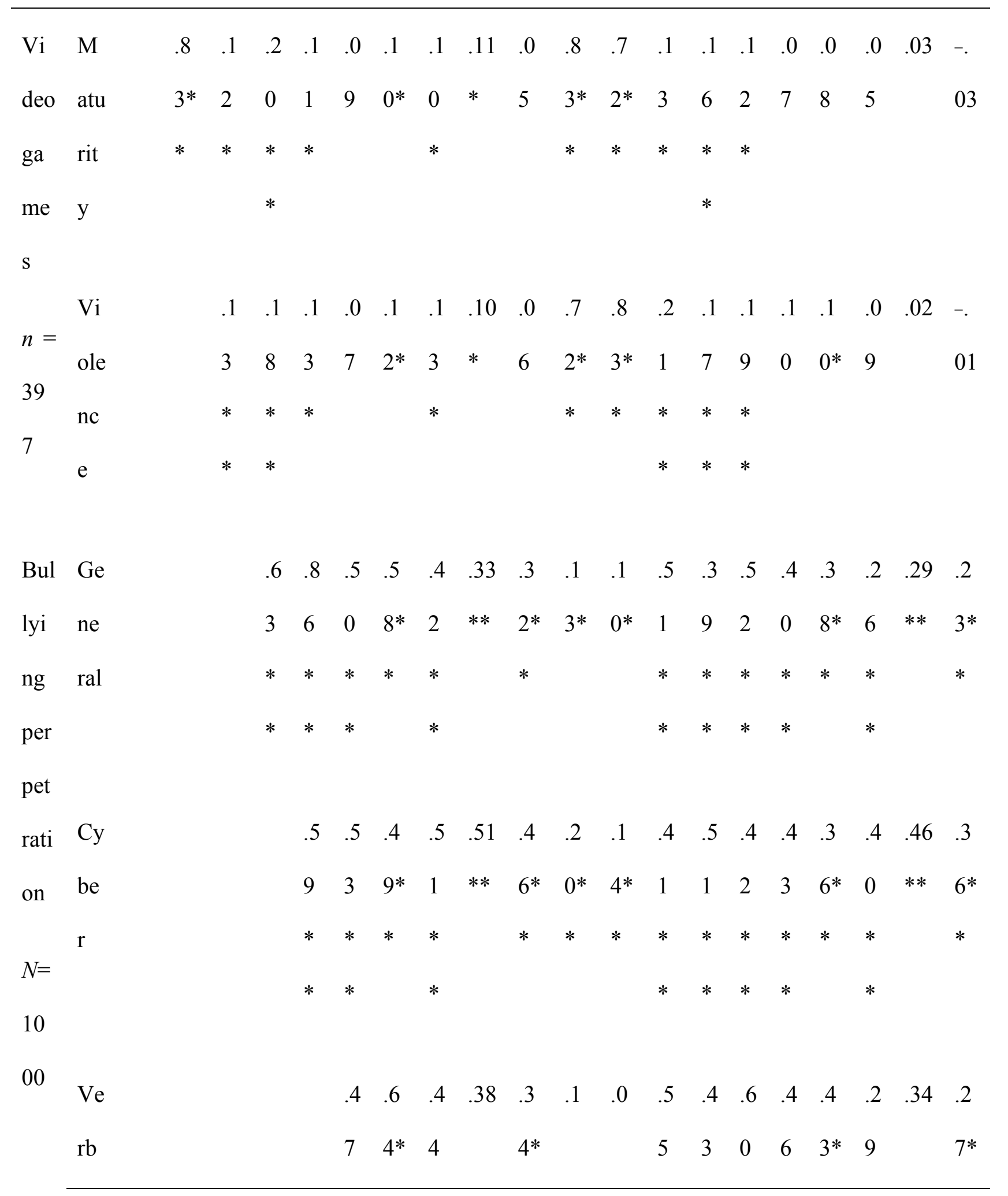




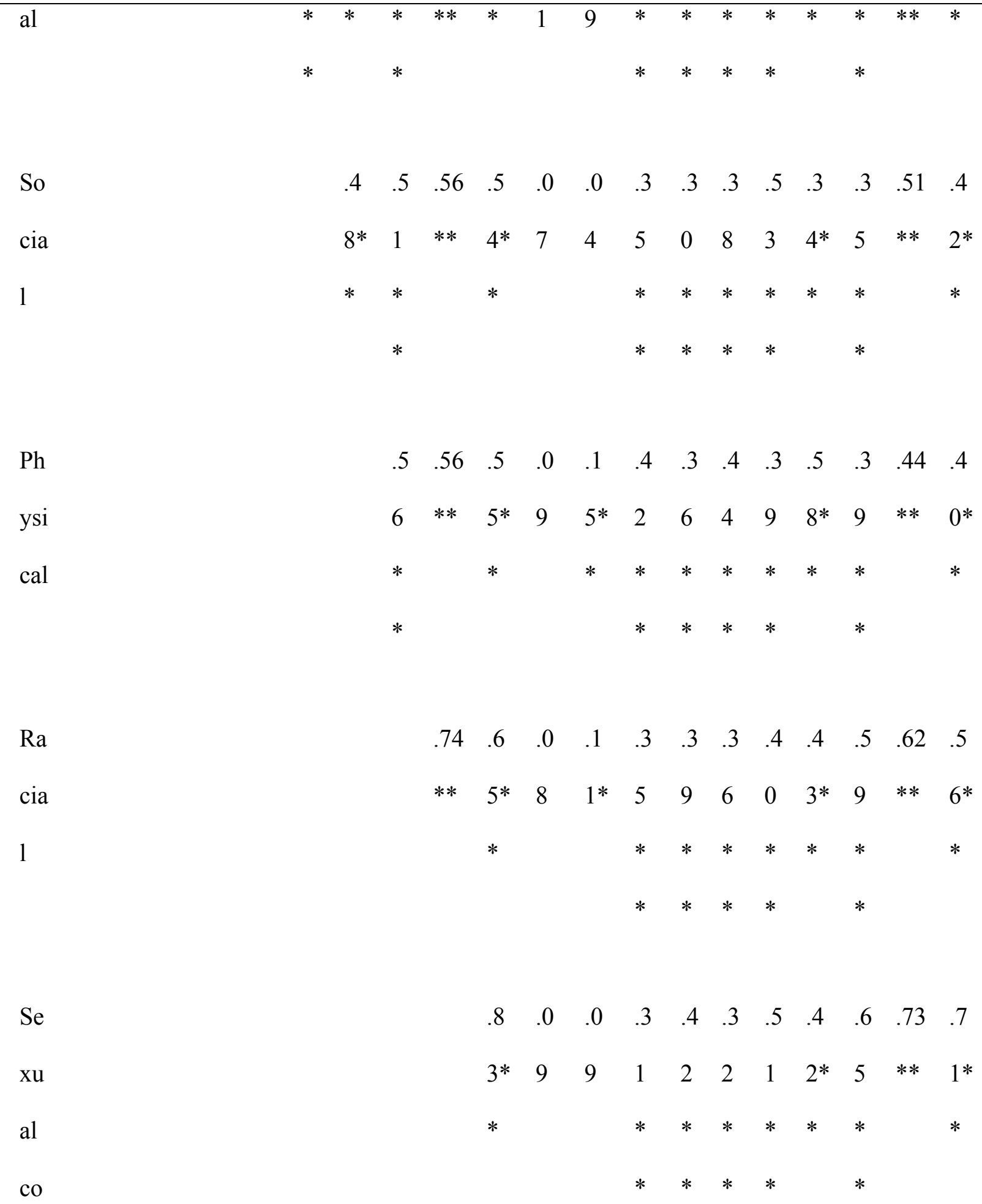


$\mathrm{m}$

me

nts

$\mathrm{Se}$

$\begin{array}{llllllllll}.0 & .0 & .2 & .3 & .2 & .4 & .4 & .5 & .69 & .6\end{array}$

$\mathrm{xu}$

$\begin{array}{llllllllll}3 & 4 & 7 & 4 & 8 & 4 & 0 * & 7 & * * & 6^{*}\end{array}$

al

be

ha

vi

or

\section{Chi}

ld

rep

ort

Vi M

deo atu

ga rit

me y

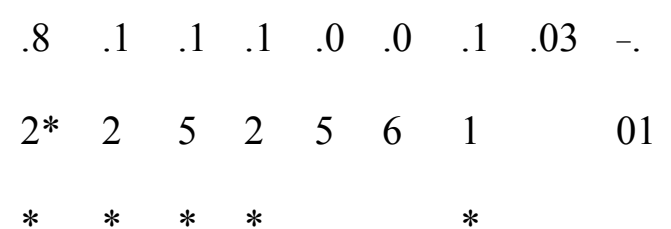




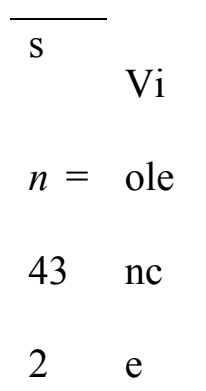

Bul Ge

lyi ne

ng ral

per

pet

rati $\mathrm{Cy}$

on be

$N^{\mathrm{r}}$

$=$

$10 \mathrm{Ve}$

00 rb

al

So

cia $\begin{array}{lllllll}.7 & .8 & .5 & .6 & .4 & .34 & .2\end{array}$

$\begin{array}{lllllll}2 & 8 & 3 & 4 * & 1 & * * & 9 *\end{array}$

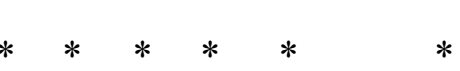

$\begin{array}{llllll}.7 & .5 & .5 & .5 & .46 & .3\end{array}$

$\begin{array}{llllll} & 3 & 3 * & 1 & * * & 9 *\end{array}$

* * * * *

$\begin{array}{lllll}.5 & .6 & .4 & .39 & .3\end{array}$

$33^{*} 2 * * 3 *$

$*$

*

$\begin{array}{llll}.4 & .5 & .61 & .5\end{array}$

$9 * 6 \quad 5 *$ 
1

$\mathrm{Ph}$

$\begin{array}{lll}.5 & .50 & .4\end{array}$

ysi

$1 * * 6 *$

cal

$\mathrm{Ra}$

$\begin{array}{ll}.74 & .7\end{array}$

cia

** $\quad 1 *$

1

$\mathrm{Se}$

$\mathrm{xu}$

5*

al

co

$\mathrm{m}$

me

nts

$\mathrm{Se}$

$\mathrm{xu}$

ACCEPTED MANUSCRIPT 
ACCEPTED MANUSCRIPT

al

be

ha

vi

or

${ }^{*} p<.05 .{ }^{* *} p<.01$ (two-tailed). 
Table 3 Spearman Correlations between Video Game Preferences and Bullying Perpetration, Separated by Child Gender

\begin{tabular}{|c|c|c|c|c|c|c|c|c|}
\hline & \multicolumn{4}{|c|}{ Video game maturity } & \multicolumn{4}{|c|}{ Video game violence } \\
\hline & Parent & atings & Child & atings & Parent & ratings & Child & atings \\
\hline $\begin{array}{l}\text { Child } \\
\text { Gender }\end{array}$ & Male & Female & Male & Female & Male & Female & Male & Female \\
\hline$n$ & 211 & 186 & 229 & 203 & 211 & 186 & 229 & 203 \\
\hline \multicolumn{9}{|l|}{ Video } \\
\hline \multicolumn{9}{|l|}{ game } \\
\hline Maturity & - & - & - & - & $.80 * *$ & $.67 * *$ & $.80 * *$ & $.67 * *$ \\
\hline Violence & $.80 * *$ & $.67 * *$ & $.80 * *$ & $.67 * *$ & - & - & - & - \\
\hline
\end{tabular}

Bullying

perpetratio

$\mathrm{n}$ 


\section{ACCEPTED MANUSCRIPT}

General

.05

.07

.06

.08

.04

$.12 \quad .10$

.08

Cyber

.12

$.24 * *$

$.14 *$

.10

.08

$.23 * *$

.09

.10

Verbal

.08

$$
.08
$$

.07

.08

$$
-.02
$$

.12

.11

.06

Social

.06

.08

.04

.01

.06

$.02 \quad .06$

.06

Physical

.03

$$
.03
$$

$.03-.06$

.03

.07

.08

.03

Racial

.09

.10

$.13 * \quad-.02$

.10

.12

.10

.05

Sexual

.08

.11

$.05-.07$

.07

.10

.01

\begin{tabular}{|c|c|c|c|c|c|c|c|}
\hline Sexual & $<.01$ & .11 & $<.01$ & -.10 & $<.01$ & .10 & $<.01$ \\
\hline
\end{tabular}

.01

comments

${ }^{*} p<.05 .{ }^{* *} p<.01$ 
Table 4 Ordinal Logistic Regression Analyses of Video Game Preferences and Bullying Perpetration

Parent reports $N=397$

General bullying perpetration Cyberbullying perpetration

Pseudo Log Coefficient Pseudo Log Coefficient

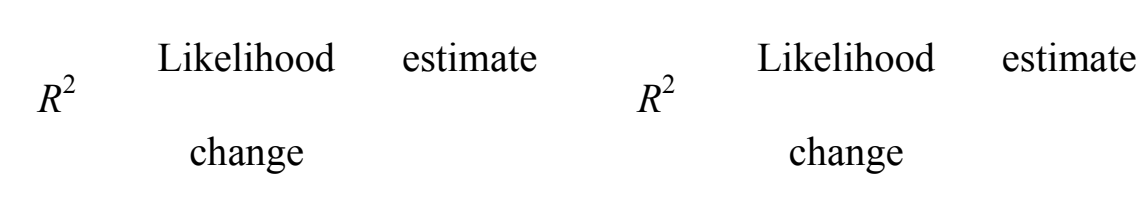

( $d f$ change $) \quad(d f$ change $)$

STEP 1

$.0591 .66^{* *}$

$.5372 .13 * *$

(3)

(4)

General bullying

$-$

$-$

$3.86^{* *}$

Child gender

$.91^{* *}$

.74

Child age

.04

.27

STEP 2

$.05255 .88^{* *}$

$.57 \quad 37.22 * *$

(2)

(2) 


\section{ACCEPTED MANUSCRIPT}

Maturity

$-.03$

Violence

.14

.31

STEP 3

$.05 \quad-0.10(2)$

$.69 \quad-4.47(2)$

Child Gender ×

$-.02$

$-.76$

Maturity

Child Gender $\times$

$-.06$

$-.52$

Violence

Child reports $N=432$

STEP 1

$.04 \quad 101.04 * *$

$.50 \quad 134.84 * *$

(2)

(3)

General bullying

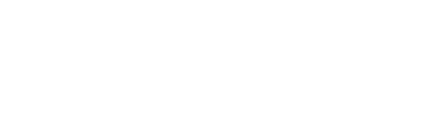

General bullying perpetration

Cyberbullying perpetration

$-$

$-$

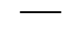

$3.21^{* *}$

Child gender

$.85^{* *}$ .36 


\section{ACCEPTED MANUSCRIPT}

Child age

STEP 2

Maturity

Violence

STEP 3

Child Gender $\times$

$.05 \quad 347.98 * *$

(2)

$-.17$

.29

$1.07 * *$

$.10 \quad-4.52(2)$

$-.48$

.32

Maturity

Child Gender ×

.21
$.53 \quad 49.91 * *$

(2)

.10

$-.27$

$.56 \quad-0.55(2)$

Violence

Note. - indicates the variable was not applicable for the associated analysis. Pseudo $R^{2}$ involves the Nagelkerke Pseudo $R^{2}$ statistic.

$* p<.05 . * * p .01$ 